\title{
INFORMATION TERRORISM: INTERPRETIVE AND ATTRIBUTIVE ANALYTICS OF THE PHENOMENON
}

\author{
Viktoriia Puhach \\ PhD in Political Science, Associate Professor, \\ University of Educational Management, Ukraine \\ e-mail: 1002vp@i.ua, orcid.org/0000-0002-748-6427 \\ Olena Ishchenko \\ $\mathrm{PhD}$ in Philosophical Science, Associate Professor, \\ Taras Shevchenko National University of Kyiv, Ukraine \\ e-mail: rebluesun@ukr.net, orcid.org/0000-0003-3832-2403
}

\section{Summary}

This article aimed to meaningfully identify information terrorism as a special type of terrorism and as a separate promising area of research, as well as to justify the need to create a holistic view of the phenomenon of information terrorism. For achieving this goal, next research methods were used: historical, logical, analysis, synthesis, deduction. This scientific paper attempts to distinguish information terrorism as "intangible violence", aimed at reproducing the constantly confused, discombobulated, insecure public, by spreading and development of information products that can cause feelings of fear, anxiety, panic, stress. Diversification of information and communication means and sources of information, almost total dependence of modern individual and society on information, devaluation of facts have created favorable conditions for the emergence and spread of information terrorism. Information terrorism should be taken as an act or series of acts of intrusion into the information and communication space, which aims to intimidate a wide audience, create socio-psychological tension, anxiety, in order to obtain desired policy results in any case. Also there is can be a major threat of transformation of information in 'weapon of mass destruction' influence of this 'massive destruction' will continue to be felt for a long time.

Keywords: communicative interactions, fear, information-terrorist manipulations, intangible violence, media production, social networks.

\section{DOI https://doi.org/10.23856/3936}

\section{Introduction}

With the development of information and communication technologies, intensification of information processes, significant expansion of technological capabilities to construct a plurality of realities that call into question "real reality", the growing social significance of virtual reality, not incorporated into which is perceived as a deviation or marginality, problem of information terrorism becomes especially relevant. This phenomenon is a logical answer to the information society. The technical and technological achievements of today have turned the media and communication into a powerful tool of manipulative influence, and have become negative motivating stimuli for information and terrorist activities. Today, information terrorism not only poses a serious threat, but also demonstrates a tendency to further intensify and, consequently, increase the number of its victims.

In view of this, issues related to clarifying the specifics of information terrorism, its essence and content are of particular importance. Lack of scientific and theoretical research 
on these issues led to the research applications and objectives of this article. The theoretical and methodological ark here is set by the constellation of social processes associated with the transition from industrial to post-industrial society in which violence has acquired a new image.

\section{Conceptual analysis of information terrorism}

"Everything is good in its season" - says a famous proverb. Information terrorism appears where and when favorable conditions for its emergence have developed. Most often such conditions are the rapid development of information and communication technologies, the transformation of the media into an industry with all the hallmarks of an industrial approach to media production, a significant increase in communication interactions through information technology in social networks, chats, blogs and forums. In other words, information terrorism is not an accidental phenomenon, but a natural product of a society saturated with various means of communication which are able to quickly process, send and receive large amounts of information.

It should be noted that information manipulation, shifting of facts, misinformation as integral components of information terrorism have always been considered as an important tool for achieving military and socio-political goals. It is worth recalling from the history of philosophy one of the oldest monuments of the ancient world - a treatise by the ancient Chinese strategist and philosopher Sun Tzu “The Art of War". Prescribing specific recommendations for using information to gain certain advantages and ensure victory over the enemy, the philosopher understood war as a "way of fooling", emphasizing: "if you could do anything, show the enemy as if you could not; if you used something, pretend you didn't use it; no matter how close you was, pretended you was far away; even if you was far away, advertise as if you was close; entice him with benefits; brought him to frustration and take him; if he had everything, be prepared; if he was strong, avoided him; causing anger, brought it to a state of frustration..." (Sun-tszy, 2014: 8-11). A similar position was highlighted in the prominent ancient Indian monument of government called "Arthashastra", which stated that the difficulties of the enemy should be created, even at the cost of deception, "sowing discord": "if the archer fired an arrow, it must kill one or not kills. Thought, thrown consciously, kills even that which is just emerging" (Arthashastra 1959: 429). We believe that there is no need to reconstruct the history of information confrontation. These examples, in our opinion, are enough to convince the reader that information aggression has always been and is an integral attribute of socio-political life, and information terrorism, even in its infancy, has always served to achieve various political goals of various kinds.

Of course, it would be an oversimplification to equate modern information-terrorist attacks with the information-psychological influences of the Sun Tzu or Kautili's times, but their commonality should not be ignored. Undoubtedly, the main integrating factor here is the goal, the achievement of which involves intimidation, demoralization, the creation of socio-psychological tension, bordering on moral panic.

Of course, modern information terrorism instrumentalizes "disfunctional fear", makes consumers of information "lose their minds" and despair. The appeal to fear by information terrorists is well-founded from several points of view. First, fear is contagious (viral): "it is only necessary for someone to be afraid of something, as immediately the concern spreads to others, and they, in turn, transmit the fear further" (Svendsen, 2010: 27). Second, fear is a resource of power that can be successfully used to achieve socio-political goals, because "fear adjusts the mind to the perception of certain information, it can be used against opponents" (Svendsen, 2010: 30). As is well known, political struggle involves not only a direct confrontation with the enemy, but also requires a change (adjustment) of his worldview and social 
attitudes. Third, fear paralyzes rational-critical thinking, it interferes with mental activity, as a result of which the human mind loses the ability to adequately perceive reality. Thus, there is a favorable situation for the imposition of ideas, the spread of ideological fictions, changing values, fabrication of needs, modification of behavior and all sorts of speculation, and thus create favorable conditions for spiritual violence.

At the same time, fear as such, especially does not require additional use of force, direct physical acts of violence. After all, as the British researcher F. Furedi notes, the "culture of fear" now dominates: "today, many of our fears are often not based on personal experiences. Compared with the past, people living in Western societies have less familiarity with pain, suffering, debilitating disease and death than ever before. And yet, despite an unprecedented level of personal security, fear has become an ever-expanding part of our life" (Furedi, 1997: vii).

Terrorists resort to extreme measures (murder, destruction, hostage-taking, etc.), mostly for the reason that only the image of death (fear of death) can attract increased audience attention, and, as we know, publicity is a necessary component of the effectiveness of terrorist activities: "the success of a terrorist operation depends almost entirely on the amount of publicity it receives" (Schmid, 2004: 208). In other words, "extreme measures" of terrorists are only a tool to influence as large an audience as possible. In this context, it is worth recalling the ancient Chinese aphorism, which very aptly reveals the essence of terrorism: "to kill one is to intimidate hundreds".

Information terrorism as a special type of terrorism should not be considered from the standpoint of physical violence. Cultivation of fear, "feeding" it by means of manipulating information messages, the continuous state of "intimidated consciousness", obviously, allow to achieve socio-political goals without resorting to direct acts of violence. This is the insidiousness of information terrorism, which resorts to targeted destructive information influence by means of covert coercion with the help of meaning-creating information products. The treacherous, diabolical nature of information terrorism is hidden in the difficulty of recognizing it for the average person, as it remains unnoticed by him. Modern information technologies and their technical capabilities allow to give the pretended authenticity of any message. An outright lie, an exaggeration can for some time, until they are exposed, acquire signs of authenticity with the help of illustrations (photographs, videos, testimonies of "eyewitnesses"), which increase the probability of the information message. So, in particular, the information site Vesti.ru on January 4, 2016, referring to "photos and video from the phone of one of the fighters of "Azov", to which hackers gained access" spread information that allegedly in the Ukrainian regiment "Azov" ISIS fighters. However, with the help of the geographic service Wikimapia, BBC journalists found out that all 18 photos and two videos presented on the site were taken by the Isolation Foundation, so they are fabricated, and the fund itself is located in Russian-occupied Donetsk. Another example of information terrorism is related to the Boeing 777 crash that occurred on July 17, 2014 in the sky over the Donetsk region. In order to accuse the Ukrainian Air Force of involvement in the destruction of the MH17 passenger flight, on November 14, 2014, the Russian First Channel aired a story showing a "satellite image" of the "moment when the Ukrainian fighter on the MH17 attacked". The "authenticity" of the "satellite image" was confirmed by the "authoritative opinion" of the First Vice-President of the Russian Union of Engineers I. Andrievsky, who noted that a careful analysis of the image made by representatives of the Union did not reveal any signs of forgery, its authenticity. In fact, the "photo" turned out to be fake, because it violated the proportions of objects relative to the ground, in particular, Boeing, if you believe the "satellite image" is several kilometers long, which is absurd and pure nonsense. (TOP 20 Fakes of Russian Media). Unfortunately, these examples show the leveling of the principle of journalism, formulated in 1921 by one of The Manchester Guardian's former 
editors C.P. Scott: "Facts are sacred, but comment is free", still "even though, ideally, comment is only respectable if it is founded on proven facts" (Marthoz, 2017: 53).

In their pursuit of sensation, "philosophy of attracting attention" (N. Luhmann), ratings, relevance, credibility, sales - modern media, ignoring the imperative of "sanctity of facts", turning information into comments, devalue the latter as a "fixed category" with a clearly defined content as "inviolable facts" or "pieces of reality" (Kean, 2015: 139). In other words, the reality in which something is happening, and the reality about which we are told are not the same thing, the reality is deprived of fact, there is an "industry for facts" which is mass-produced. Therefore, the media skillfully "deviating from the truth", mostly aimed not at impartial informing the public, to broadcast information in the aspect of knowledge, but to create information messages, replication and distribution of pre-finished products. This makes it impossible for most consumers of information to form their own opinions, thus violating the fundamental human right to "habeas mentem - the inviolability of consciousness" (Zolo, 2010: 18).

In the modern world, it is difficult to speak of consciousness as an "invincible fortress", "that we are masters of what our minds accept or reject" (H. M. Enzensberger). Unfortunately, a person is no longer able to hide from the world due to his own mind, he is not a "last refuge", falling under constant "information attacks" is in the system of suggestions, illusions, delusions.

This is confirmed by the emergence of the phenomenon of "industry of consciousness". The latter develops with such speed and in such various forms, that it has outgrown our understanding and our control. A notable feature of the "consciousness industry" is the lack of production, instead, it is "it is an intermediary, engaged only in production's secondary and tertiary derivatives, in transmission and infiltration, in the fungible aspect of what it multiplies and delivers to the customer" (Enzensberger, 1982: 5). The German scholar Enzensberger emphasizes that the industry of consciousness is the leading branch of modernity, and those who are involved or involved in power are well aware of this, waging fierce public "political, economic, cultural, legal, religious, etc. battles" in the information field. Increasingly, there is a marked intensification of information terrorists, who cultivate fear and panic by means of information sabotage.

Therefore, let us assume that both individual public politicians and organizations involved in information terrorism should now be considered as the main incubator of violence. After all, as the American journalist and writer M. Thompson rightly remarked, verbal violence leads to physical violence.

The analysis allows us to offer our own vision of the concept of information terrorism, which should be understood as an act or series of acts of intrusion into the information and communication space, which aims to intimidate a wide audience, create socio-psychological tension, anxiety, in order to obtain desired policy results in any case.

Subjects of information terrorism, abusing the right to information, resort to information-terrorist act - the targeted use of information-psychological technologies in order to destructively influence the consciousness and behavior of people. Today, there are many technologies of "intangible violence", the use of which allows the subjects of information terrorism to achieve their specific goals. At the heart of all technologies (operations) there is a manipulative influence, the characteristics of which are: first, the object of manipulation appears as a tool to achieve the goals of the subject of manipulation, secondly, the hidden nature of influence, and thirdly, high the degree of emotionality of information messages. A well-organized and planned information-terrorist act "might succeed in occupying our minds by creating a climate of fear, thereby manipulating target audiences at the emotional level" (Schmid, 2004: 207-208).

Of course, within the framework of this study it is impossible to consider all the variety of information-terrorist manipulations. However, it is safe to say that through misinformation, 
propaganda, suggestion, exploitation of the emotional and sensory sphere of man, simplified formulas such as "friend -enemy", "good - evil", attacks by information terrorists are aimed at forming misconceptions, demoralization, deliberately creating an atmosphere of fear and intimidation, uncertainty and apocalyptic sentiments, consistent discrediting of state institutions and de-legitimization of the political system as a whole. In this aspect, information terrorism is similar to "classical" terrorism, as both "inculcate fear and adversely affect normal, daily life by threatening personal safety, thereby tearing at the social fabric of a country by destroying its business and cultural life and the mutual trust upon which society is based" (Hoffman, 2007: 3).

\section{Virtualization of information terrorism}

The subjects of information terrorism actively use the "classic" media to achieve their goals, however, in order to achieve maximum efficiency in publicizing their actions, they must take their temporitum. After all, "the temporitum of the weekend destroys the dynamics of the event" (Pochepcov, 2011: 113), respectively, this time is not particularly good for actively influencing the minds of the mass audience. Information terrorists create products for the media, and the latter, in turn, respond to them with almost unbridled eagerness, proving unable to ignore an event ... fashioned specifically for their needs. Therefore, it is fair to say that the relationship between terrorists and the media is interpreted by many researchers as symbiotic. For example, J. E. Lukaszewski emphasizes that the media and terrorists feed each other ("feed off each other"), and together they "create a dance of death", B. L. Nacos describes the relationship between the media and terrorists as "strange bedfellows in a marriage of convenience" (Chuipka, 2016: 52). Obviously, such relations become extremely threatening and require appropriate reactions. This was emphasized, in particular, by the OSCE Representative on Freedom of the Media, D. Mijatović, who called on editors and publishers and state-owned media directly or through representatives to stop corrupting the profession, stop earning and gain influence over blood, hate speech and limited thinking. According to D. Mijatović, propaganda is another ugly scar on the face of modern journalism, so there is an urgent need to cleanse journalism of fear, propaganda and frustration with everyday reality. Without critical journalism, D. Mijatović concludes, democracy is harmed, and deliberate misinformation becomes the norm. (Propaganda and Freedom of the Media, 2015).

The rapid spread of the Internet in the late twentieth century. The 21 st century, characterized by the absence of a "gatekeeper" who would select and edit information, lightness and open access and rapid exchange of information, reaching a wide audience, provoked its active use by information terrorists as a powerful information and propaganda tool.

Without diving into the methods by which the Internet is used for information and terrorist purposes, we note that as media platforms, information terrorists are increasingly using Youtube, social networks Facebook and Twitter. This can be explained by the fact that, firstly, in social networks, "users can encounter statements they may consider highly contentious or extremely offensive - even when they make no effort to actively seek out this material", and secondly, social networks "can enable the easy, fast and widespread dissemination of misinformation" (Kapko, 2016). Beside this, research conducted by the Pew Research Center roughly one-in-five social media users have changed their minds about a political candidate, or a social issue, because of the material they encountered on social media (Duggan \& Smith, 2016).

In our opinion, Twitter is particularly vulnerable to information terrorism. This assumption is based on the characteristics of Twitter itself as a form of communication.

As you know, Twitter messages ("tweets") are limited to 140 characters, which prevents in-depth discussion and critical perception of information: "by demanding simplicity, Twitter 
undermines our capacity to discuss and, subsequently, to think about issues and events in more complex ways" (Ott, 2017: 61). Beside this, Twitter has a unique feature of retweeting as a powerful mechanism of information sharing. Thus, Twitter is an excellent platform for disseminating information, where the original tweet is propagated to a new set of audiences, namely, the "followers" of the retweeter. Another feature of Twitter, favorable for information and terrorist attacks, is that this social network is more likely to spread emotionally colored messages. S. Stieglitz and L. Dang-Xuan emphasize this circumstance: "we find that emotionally charged Twitter messages tend to be retweeted more often and more quickly compared to neutral ones". As we know emotions have a powerful persuasive potential, and emotional messages attract more attention: "attentional processes are also shown to have an impact on emotional contagion, which is the spread of mood and affect through populations by simple exposure" (Stieglitz \& Dang-Xuan, 2013: 217-222). In addition, it is "negative emotions" that increase popularity on Twitter. Hence, Twitter breeds dark, degrading, and dehumanizing discourse; it breeds vitriol and violence. However, Twitter is trying to reduce aggression and other negative manifestations.

Research by Twitter users also gives some reason to talk about the vulnerability of this social network to information terrorism. For example, compared to Facebook users, Twitter users are more focused on public figures and users they do not know: just $15 \%$ of Twitter users say that they mostly follow people they know personally, while nearly half (48\%) say they mostly follow people they do not know personally (Duggan \& Smith, 2016). Thus, a significant part of Twitter users uncritically consuming and disseminating information materials from strangers, significantly increase the chances of information terrorists to carry out effective information and psychological attacks.

Of course, other social networks are also actively used by information terrorists. For example, in early March 2014, such Russian social networks as "VKontakte" and "Odnoklassniki" launched powerful anti-Ukrainian propaganda campaigns to spread and support separatism in Ukraine, the ideologue of the "Russian world". In particular, the "Novorossiya group" was created on the "VKontakte" social network called for the fight against Ukraine and the creation of an independent republic. The Ukrainian Internet community has been systematically subjected to massive information and terrorist acts by anti-Ukrainian groups created on the mentioned social networks. The destructive content of the latter focused on emotional arousal, spreading panic rumors, feelings of anxiety, fear, cynical distortion of history to deny the existence of a separate Ukrainian nation, instilling the idea of artificial Ukrainian state, resuscitation of imperial and Soviet ideological stereotypes, incitement to hatred. As "VKontakte" and "Odnoklassniki" ranked first in the ranking of social networks among Ukrainians, it was obvious that their attacks of "non-military influence" were an important component of the general information aggression against Ukraine carried out by the Russian Federation. In view of this, on May 15, 2017 The President of Ukraine Petro Poroshenko signed Decree №133/2017 on the implementation of the decision of the National Security and Defense Council of Ukraine of April 28, 2017 "On the application of personal special economic and other restrictive measures (sanctions), as a result of which access to Ukraine was blocked Internet resources "VKontakte", "Classmates" sites "Mail.ru", "Yandex" and anti-virus programs "Kaspersky Lab", "Dr.Web" for 3 years. Such a step by the Ukrainian state to protect its information space provoked a mixed reaction from the world community. In particular, the Secretary General of the Council of Europe, T. Jagland, expressed concern about the above-mentioned Decree, noting that blocking social networks, search engines, postal services and information websites is contrary to our common understanding of freedom of expression and freedom of the media. Moreover, such general broad prohibitions do not comply with the «principle of proportionality". A similar 
position was expressed by the Executive Director of Reporters Whithout Borders Germany C. Mihr. In his opinion, the activate to block Russian Internet resources was an unacceptable attack not only on freedom of speech, but also on the press. According to C. Mihr, the social networks "VKontakte" and "Odnoklassniki" are important for freedom of speech, because people can communicate on these platforms. Emphasizing that the mass media should not take part in the information war, and that the war between Russia and Ukraine needs truthful information, C. Mihr believes that blocking news distributors is an attack on information freedom. This is unacceptable under any circumstances.

Meanwhile, the ban on access to Russian Internet resources is due to several important reasons, such as: cybersecurity (Russia's FSB had access to Ukrainian users' accounts); political (a lot of propaganda and separatist information directed against Ukraine was published on Russian social networks); economic (funds from taxes for advertising published on social networking sites went to the Russian budget).

In addition, it should be borne in mind that the classical media have lost their monopoly on setting the agenda. Currently, an important factor in the formation of the latter are the communities of social networks, for which the source of information and its reliability are secondary issues, instead much more important is compliance with the rules of message selection. Among them, one of the main ones is the conformity of the information product to the position of the community, its picture of the world. So, the leveling of professional journalistic standards (freedom of cyberspace), the development of an anonymity culture allows people to "post", publish and say whatever they want, without any restrictions, which makes it much easier to manipulate public opinion, mass consciousness and behavior of many people. As a result, «truth becomes just... a commodity that can be bought, sold, packaged and reinvented» (Kean, 2015: 162).

Probably the German researcher N. Luhmann is right in his saying that any reality is a construction. Meanwhile, the modern science and technology reached that level of development where the latest information and communication technologies artificially create realities that have a devastating effect on the human psyche, pose a direct threat to the information security of society and the state."Real reality" has lost its significance, it is unclaimed, but an epidemic of information and psychological violence is unfolding, the number of victims of which is steadily growing.

\section{Conclusions}

The rapid development of information and communication technologies has created very favorable opportunities for the manipulation of information flows, destructive information and psychological impact on both individual and large groups of people. Nowadays there is a real threat of turning information into a "weapon of mass destruction", the destructive factors of which will be felt for a long time. And in this context, special attention has been drawn to the problem of information terrorism, the emergence and spread of which is provoked by the expansion of communicative interactions carried out by people through the latest information technologies.

Analyzing the phenomenon of information terrorism, the authors consider it as a special type of terrorism aimed at creating a constantly confused, confused, insecure public, a means of purposeful development and dissemination of information products that can cause fear, anxiety, panic, stress. No less fundamental feature of information terrorism is the complexity of its identification. Digitalization allows information terrorism, even for a certain time, to act as an "invisible hand", during the secret act of which there is "intangible" violence in the form of information-terrorist acts. 
Raising the problem of information terrorism in this article, its authors trying to emphasize the importance of a comprehensive study of this phenomenon, the need to form a holistic conceptual understanding of information terrorism. Besides that, there is a need for further, more in-depth study of the problem of protecting society and the individual from harmful information influences, preventing the spread of information and psychological violence.

Certainly hopeless in the context of the spread of the global media network and the making of the global network society to talk about the society closedness and the individual to perceive the effects of information and communication technologies, the creation of "information reserve". At the same time, the era of "space/time compression", unhindered transmission of information and instantaneous communication has exacerbated the problem of the correlation between freedom of speech and collective/individual information and psychological security.

\section{References}

Arthashastra ili nauka politiki (1959). [Arthashastra or the science of politics]. Moscow Leningrad: Izdatelstvo Akademii nauk SSSR. [in Russian]

Chuipka, A. (2016). The Strategies of Cyberterrorism: Is Cyberterrorism an effective means to Achieving the Goals of Terrorist? Retrieved from https://www.semanticscholar.org/paper/TheStrategies-of-Cyberterrorism\%3A-Is-Cyberterrorism-Chuipka/c5e26c74143b47f608f05e5c4a c862191452d1d3\#related-papers

Duggan, M., Smith, A. (2016). The Political Environment on Social Media. Retrieved from https://www.pewresearch.org/internet/2016/10/25/the-political-environment-on-social-media/ Zolo, D. (2010). Demokratiya i slozhnost: realisticheskiy podhod [Democracy and Complexity: A Realist Approach]. Moscow: Izdatelskiy dom Gosudarstvennogo universiteta - Vysshey shkoly ekonomiki. [in Russian]

Enzensberger, H.M. (1982). Critical Essays. New York: Continuum.

Furedi, F. (2002). Culture of Fear: Risk-taking and the Morality of Low Expectation. London New York: Continuum.

Hoffman, B. (2007). A Form of Psychological warfare. eJournal USA, 5/31, 1-6. Retrieved from http://usinfo.state.gov/journals/itps/0507/ijpe/hoffman.htm

Kapko, M. (2016). Twitter's on 2016 presidential election is unmistakable. CIO, Nov 3. Retrieved from https://www.cio.com/article/3137513/twitters-impact-on-2016-presidentialelection-is-unmistakable.html

Kean, D. (2015). Demokratiya i dekadans media. [Democracy and media decadence]. Moscow: Izdatelskiy dom Vysshey shkoly ekonomiki. [in Russian]

Marthoz, J.-P. (2017). Terrorism and Media. A Handbook for journalists. Paris: published by UNESCO. Retrieved from https://unesdoc.unesco.org/ark:/48223/pf0000247074

Ott, B.L. (2017). The age of Twitter: Donald J. Trump and the politics of debasement. Critical Studies in Media Communication, 34(1), 59-68. DOI: 10.1080/15295036.2016.1266686. Retrieved from http://dx.doi.org/10.1080/15295036.2016.1266686

Pochepcov, G. (2001). Informaciya i dezinformaciya. Kiev: Nika-Centr, Elga. [in Russian]

Propaganda and Freedom of the Media. Non-paper of the OSCE Office of the Representative on Freedom of the Media (2015). Vienna: Organization for Security and Co-operation in Europe. Retrieved from https://www.osce.org/files/f/documents/b/3/203926.pdf

Schmid, A. P. (2004). Frameworks for conceptualizing terrorism. Terrorism and Political Violence, 16 (2), 197-221. DOI: 10.1080=09546550490483134. Retrieved from https://www. tandfonline.com/doi/pdf/10.1080/09546550490483134 
Stieglitz, S., Dang-Xuan, L. (2013). Emotions and Information Diffusion in Social MediaSentiment of Microblogs and Sharing Behavior. Journal of Management Information Systems, 29 (4), 217-247. DOI: 10.2753/MIS0742-1222290408. Retrieved from https://www. researchgate.net/publication/259704042_Emotions_and_Information_Diffusion_in_Social_ Media_-_Sentiment_of_Microblogs_and_Sharing_Behavior

Sun-tszy (2014). Mystetstvo viiny [The art of war]. Kyiv: Ariy. [in Ukrainian]

Svendsen, L. (2010). Filosofiya straha [The philosophy offear]. Moscow: Progress-Tradiciya. [in Russian]

TOP 20 Feikiv Rosiiskykh Media (ZMI) [TOP 20 Fakes of Russian Media (Mass media)] Retrieved from https://mip.gov.ua/files/broshury/top_20_feikiv_ros_media.pdf [in Ukrainian] 